\title{
Preferenties ... referenties
}

Citation for published version (APA):

Kruitwagen, R. F. P. M. (2008). Preferenties ... referenties: besluiten en beslissingen binnen de gynaecologische oncologie. Maastricht University. https://doi.org/10.26481/spe.20081121rk

Document status and date:

Published: 21/11/2008

DOI:

10.26481/spe.20081121rk

Document Version:

Publisher's PDF, also known as Version of record

\section{Please check the document version of this publication:}

- A submitted manuscript is the version of the article upon submission and before peer-review. There can be important differences between the submitted version and the official published version of record.

People interested in the research are advised to contact the author for the final version of the publication, or visit the DOI to the publisher's website.

- The final author version and the galley proof are versions of the publication after peer review.

- The final published version features the final layout of the paper including the volume, issue and page numbers.

Link to publication

\footnotetext{
General rights rights.

- You may freely distribute the URL identifying the publication in the public portal. please follow below link for the End User Agreement:

www.umlib.nl/taverne-license

Take down policy

If you believe that this document breaches copyright please contact us at:

repository@maastrichtuniversity.nl

providing details and we will investigate your claim.
}

Copyright and moral rights for the publications made accessible in the public portal are retained by the authors and/or other copyright owners and it is a condition of accessing publications that users recognise and abide by the legal requirements associated with these

- Users may download and print one copy of any publication from the public portal for the purpose of private study or research.

- You may not further distribute the material or use it for any profit-making activity or commercial gain

If the publication is distributed under the terms of Article $25 \mathrm{fa}$ of the Dutch Copyright Act, indicated by the "Taverne" license above, 


\section{Preferenties ... referenties}

Besluiten en beslissingen binnen de gynaecologische oncologie 


\section{Colofon}

Ontwerp en print: Océ Business Services, Maastricht

Afbeelding omslag: Elmar Kruitwagen (www.johnnydoes.nl)

ISBN: 978-90-5681-298-O

NUR: 870

Alle rechten voorbehouden. Niets uit deze uitgave mag worden verveelvoudigd, opgeslagen in een geautomatiseerd gegevensbestand of openbaar gemaakt worden, zonder voorafgaande schriftelijke toestemming van de auteur of uitgever. 


\section{Preferenties ... referenties}

Besluiten en beslissingen binnen de gynaecologische oncologie

\section{Rede}

uitgesproken bij de aanvaarding van het ambt van bijzonder hoogleraar gynaecologie / oncologie aan de faculty of Health, Medicine and Life Sciences van de Universiteit van Maastricht

op vrijdag 21 november 2008

door

Prof. dr. Roy F.P.M. Kruitwagen

\section{Maastricht University}



Mijnheer de rector magnificus,

Zeer gewaardeerde toehoorders,

Vele besluiten en beleidsbeslissingen worden onderbouwd door te verwijzen naar de bronnen of geraadpleegde literatuur: de referenties. Echter, ik zal u laten zien dat ook persoonlijke voorkeuren, of preferenties, een grote invloed blijken te hebben. Dat de voorkeur van een patiënt een belangrijke rol moet spelen bij beslissingen die haar persoonlijk aangaan lijkt mij vanzelfsprekend. Maar binnen de geneeskunde, en zeker ook binnen de gynaecologische oncologie, blijken nu juist vaak de preferenties van de arts van doorslaggevende betekenis te zijn. Dergelijke preferentiegevoelige beslissingen vormen de rode draad door mijn betoog. Onderwerpen die onder andere aan bod komen zijn evidence-based medicine en de betekenis hiervan voor de arts - patiënt communicatie, het belang van samenwerking voor de kwaliteit van zorg, de rol van een betrouwbare dataregistratie en het realiseren van zinvolle kwaliteitsindicatoren.

\section{Evidence based medicine}

In 1972 benadrukte Archie Cochrane het grote belang van randomised controlled trials (RCT's) voor het verkrijgen van betrouwbare evidence om de vraag te beantwoorden of een bepaalde diagnostische methode of behandeling zinvol of werkzaam is. Later, in 1993, is zijn naam verbonden aan een groot internationaal samenwerkingsverband van wetenschappers, de Cochrane Collaboration. Die heeft zich ten doel gesteld om systematische reviews te schrijven over interventies in de gezondheidszorg. Het belangrijkste oogmerk daarbij is het stimuleren en ondersteunen van het gebruik van evidence-based medicine, een begrip dat in de jaren tachtig werd geïntroduceerd door David Sackett. Zijn definitie luidt:"evidence-based medicine is the integration of best research evidence with clinical expertise and patient values." In het Nederlandse leerboek 'Inleiding in evidence-based medicine' van Offringa wordt dit vertaald in "het integreren van individuele klinische expertise met het beste externe bewijsmateriaal dat vanuit systematisch onderzoek beschikbaar is. De voorkeuren, wensen en verwachtingen van de patiënt spelen bij de besluitvorming een centrale rol". Deze laatste regel is erg belangrijk en wordt mijns inziens te vaak ondergeschikt gemaakt of zelfs vergeten. 


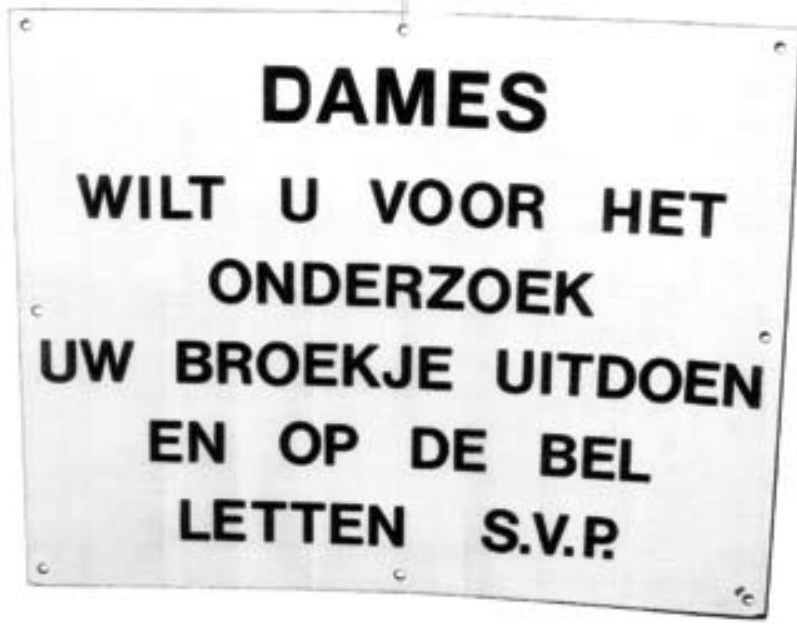

Figuur 1. Let op de bel s.v.p.

Enige tijd geleden kreeg ik een artikel uit de NRC van collega Mieke Kerkhof onder ogen met als titel 'Let op de bel s.v.p.' (figuur 1). Op een komische manier wordt ingegaan op de gewijzigde communicatie tussen de arts en patiënt en het artikel eindigt met een verwijzing naar hoogleraar gezondheidspsychologie Josine Bensing. Zij ontving in 2006 de NWO-Spinozaprijs voor haar onderzoek op het terrein van medische communicatie en de door haar ontwikkelde onderzoeksmethode om non-verbale communicatie te kwantificeren. Bensing maakt onderscheid tussen evidence-based en patient-centered medicine. Beide concepten zijn, zo stelt zij, zeer waardevol maar ogenschijnlijk tegenstrijdig. Evidence-based medicine is ziektegeoriënteerd, gebaseerd op liefst randomised controlled trials waarbij patiëntkarakteristieken worden geüniformeerd. Met andere woorden, patiëntkarakteristieken zijn voor een RCT eerder hinderlijk dan waardevol. De arts heeft, als het goed is, de evidence-based kennis. Daarom is de communicatie bij voorbaat doctor-centered. Het gevaar dreigt dat er geen rekening wordt gehouden met de wensen en voorkeuren van de individuele patiënt. Het is echter even belangrijk om de patiënt te kennen met een ziekte, als de ziekte te kennen die de patiënt heeft, of zoals het veel fraaier in het Engels verwoord wordt: "health care providers should be directed to the illness rather than to the disease". Met andere woorden: evidence-based medicine is belangrijk, maar daarbij mogen we nooit de individuele patiënt uit het oog verliezen. Het streven zou moeten zijn beide 
concepten, evidence-based medicine en patient-centered medicine, bijeen te brengen. Overigens moeten we ons realiseren dat David Sackett dit doel ook wel degelijk nastreefde binnen zijn begrip evidence-based medicine (figuur 2). Misschien komt het beter tot uiting in een meer allesomvattende term quality-based medicine die Jan Kremer, hoogleraar voortplantingsgeneeskunde, tijdens zijn oratie in 2007 gebruikte, of nog beter evidence-based patient choice, een door de Engelse psychiater en hoogleraar medische ethiek Tony Hope in 1996 geïntroduceerde term.

Hiermee kom ik bij het volgende onderwerp, de communicatie arts patiënt, hetgeen ik wil illustreren aan de hand van een patiënt bij wie de diagnose baarmoederkanker of endometriumcarcinoom is gesteld. Ter introductie, het endometriumcarcinoom is de meest frequent voorkomende gynaecologische maligniteit in Nederland. Jaarlijks worden ongeveer 1500 nieuwe gevallen gediagnosticeerd. De incidentie blijkt, in tegenstelling tot diverse andere gynaecologische maligniteiten, de afgelopen 10 jaar toe te nemen. Het endometriumcarcinoom is een typische aandoening voor de postmenopauze, slechts $6 \%$ presenteert zich bij vrouwen die nog een menstruele cyclus hebben. Een eerste en vaak ook vroeg symptoom is vaginaal bloedverlies. Omdat bloedverlies in de menopauze als abnormaal wordt gezien, wordt de arts meestal snel geconsulteerd. De diagnose wordt bijgevolg in de meerderheid van de gevallen in een vroeg stadium gesteld met daardoor vaak een gunstige prognose. Desondanks overlijden ongeveer 350 vrouwen per jaar aan de gevolgen van deze maligniteit. Het traject van de diagnostiek is simpel en blijft vaak beperkt tot het routine gynaecologisch onderzoek inclusief echoscopie, en het verkrijgen van baarmoederslijmvlies (een poliklinische procedure) voor pathologisch onderzoek om de diagnose te stellen. De behandeling is primair chirurgisch en bestaat, in Nederland, uit het verwijderen van de baarmoeder en eierstokken met eileiders. Op basis van de operatieve bevindingen, alsmede de conclusies van de patholoog die het verwijderde weefsel microscopisch beoordeelt, wordt het definitieve stadium bepaald en volgt zo nodig nog aanvullende behandeling, meestal bestraling. Na afloop van de behandeling blijft een patiënt gedurende vijf jaar onder controle. Tot zover deze samenvatting van het gehele traject van diagnose, behandeling, en follow-up van een patiënt bij wie de diagnose endometriumcarcinoom wordt gesteld. Laten we nu eens in detail enkele facetten van het ziektebeloop doornemen en daarbij de communicatie met de patiënt centraal stellen.

De patiënt meldt zich op de polikliniek met als klacht postmenopauzaal 


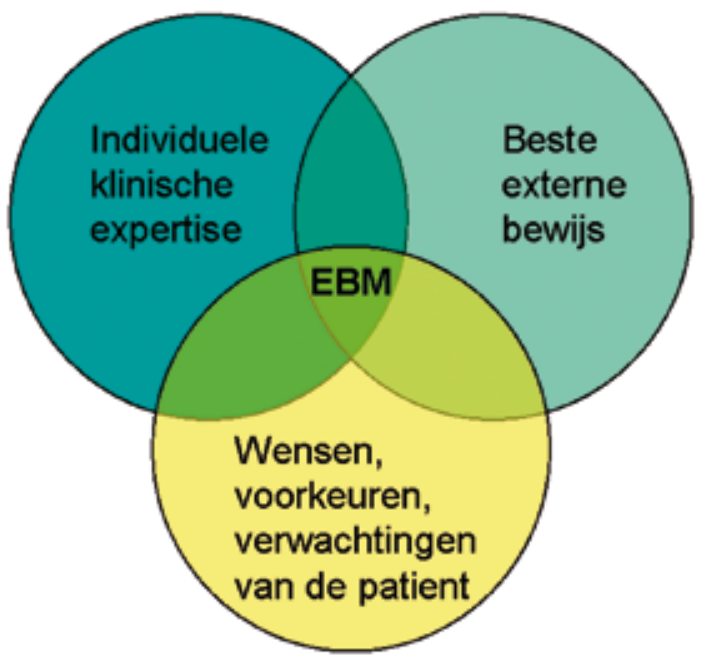

Figuur 2. De trias van Evidence Based Medicine

vaginaal bloedverlies. Vaak zal een eerste mededeling van de gynaecoloog zijn, dat er onderzoek dient plaats te vinden om de diagnose endometriumcarcinoom uit te sluiten. De kans dat de klacht daadwerkelijk het gevolg is van een endometriumcarcinoom bedraagt globaal $10 \%$. Wanneer de gynaecoloog, op basis van het verrichte onderzoek de diagnose toch vermoedt, zal hij hierover mogelijk al iets zeggen. Maar ongetwijfeld zal hij benadrukken dat het in dat geval een vaak goed te behandelen vorm van kanker is. De evidence leidt ons bij voorbaat naar een redelijk optimistisch verhaal. Ik ben van mening dat het optimisme zeker een plaats behoort te hebben in het gesprek, maar er moet toch ook enige aandacht besteed worden aan de situatie wanneer de bevindingen minder gunstig blijken te zijn. Als vervolgens de diagnose endometriumcarcinoom inderdaad wordt gesteld, en met patiënt de behandeling wordt besproken, komt de invloed van de klinische expertise en voorkeuren van de specialist pas echt goed tot uiting. Behalve dat de patiënt in aanmerking komt voor een operatieve verwijdering van de baarmoeder en eierstokken met eileiders, zijn er andere elementen in het behandelingsvoorstel waarvoor wel of niet gekozen kan worden. Moeten er wel of geen lymfklieren verwijderd worden? Is er wel of geen indicatie tot aanvullende bestraling? De evidence in de literatuur biedt blijkbaar meerdere mogelijkheden. Alle opties kennen argumenten voor en tegen, zeker wanneer je daarbij 
ook de complicaties en bijwerkingen betrekt. Een fraai voorbeeld van uiteenlopende meningen gebaseerd op dezelfde referenties zijn twee redactionele commentaren in het tijdschrift Gynecologic Oncology in 2004. Deze commentaren werden geschreven naar aanleiding van een studie bij patiënten met een vroeg stadium endometriumcarcinoom. Bij alle patiënten bestond de operatie uit het verwijderen van de baarmoeder, eierstokken en lymfklieren. Vervolgens werden de patiënten gerandomiseerd, dat wil zeggen aselect verdeeld, waarbij de ene helft wel en de andere helft geen aanvullende bestraling kreeg. Beide redactionele commentaren, één van de Amerikaanse gynaecologisch oncoloog Michael Berman, de ander van de Nederlandse radiotherapeute Carien Creutzberg, komen op grond van de resultaten van deze studie tot een volstrekt andere conclusie. Berman concludeert dat deze studie geen bewijs levert dat aanvullende bestraling zinvol is. Creutzberg vindt daarentegen dat deze studie evident aantoont dat ook na een complete stadiëring (dus met lymfklieren), aanvullende bestraling voor een deel van deze patiënten geïndiceerd is. Deze sterk uiteenlopende meningen worden met zekerheid mede bepaald door het gegeven dat beiden een andere klinische expertise en dus andere preferenties hebben. Vaak zal met de patiënt slechts één optie worden besproken. In Nederland is dat nagenoeg altijd een beperkte chirurgische ingreep en, afhankelijk van de pathologische bevindingen en leeftijd van de patiënt, zo nodig het advies tot aanvullende bestraling. Is dit terecht? Waarop is deze keuze gebaseerd? Zoals gezegd, ik ben ervan overtuigd dat de voorkeur van de specialist de belangrijkste rol speelt: de gynaecoloog die de techniek van een lymfadenectomie niet beheerst zal de toegevoegde waarde minder snel erkennen en omgekeerd. De radiotherapeut zal meer oog hebben voor de voordelen van radiotherapie en deze dan ook benadrukken.

Een dit jaar afgerond documentatieonderzoek binnen de Limburgse regio, uitgevoerd over de periode 2002 tot en met 2006 naar de behandeling van patiënten met endometriumcarcinoom illustreert de uiteenlopende preferenties. Binnen een straal van $50 \mathrm{~km}$ was het beleid tussen ziekenhuizen structureel anders. Waar in het ene ziekenhuis bij alle patiënten lymfklieren werden verwijderd, gebeurde dit nooit in een ander ziekenhuis. Deze resultaten zouden de indruk kunnen wekken dat er in deze regio nauwelijks wordt samengewerkt. Laat ik u geruststellen: na enkele wat moeizame Maastrichtse jaren hebben we door een gezamenlijke inspanning de regionale samenwerking hersteld en worden in goed onderling overleg de protocollen en richtlijnen daar waar nodig meer geüniformeerd. 
Dat er impliciet gesproken moet worden van bias op basis van preferenties wordt mogelijk nog duidelijker wanneer we de keuze tot het wel of niet verwijderen van lymfklieren bij het endometriumcarcinoom vergelijken met het in Nederland gevoerde beleid bij patiënten met een ovariumcarcinoom of eierstokkanker. Opnieuw een korte introductie met betrekking tot het ovariumcarcinoom. De incidentie ligt in vergelijking met het endometriumcarcinoom lager: ongeveer 1100 nieuwe gevallen per jaar. Daarentegen is het ovariumcarcinoom de gynaecologische maligniteit met de hoogste sterfte met ongeveer 900 gevallen per jaar. Waar het endometriumcarcinoom wordt gezien als een vorm van kanker met een gunstige prognose, geldt het omgekeerde voor het ovariumcarcinoom. Dit leidt ertoe dat het adviseren en ook toepassen van een agressievere behandeling in de vorm van radicale chirurgie en aanvullende chemotherapie bij het ovariumcarcinoom een algemeen bekend en geaccepteerd gegeven is. Echter de slechtere prognose van het ovariumcarcinoom wordt voor een groot deel verklaard door een volstrekt andere stadiumverdeling bij het stellen van de diagnose. De overgrote meerderheid, ongeveer $70 \%$, van de endometriumcarcinomen behoort op basis van de chirurgische stadiëring bij het vroege of FIGO I stadium, terwijl meer dan 60\% van de patiënten met een ovariumcarcinoom een gevorderd of FIGO III of IV stadium blijkt te hebben (tabel 1). Als we kijken naar de prognose per stadium, dan zijn de verschillen tussen beide ziektebeelden beduidend kleiner. Laten we ons nu eens richten op het klinisch vroege stadium. Met een klinisch vroeg stadium wordt bedoeld dat er vooraf aan een operatie geen aanwijzingen

\begin{tabular}{ccccccc}
\hline \multirow{2}{*}{$\begin{array}{c}\text { FIGO } \\
\text { stadium }\end{array}$} & \multicolumn{2}{c}{ Endometriumcarcinoom } & & \multicolumn{2}{c}{ Ovariumcarcinoom } \\
\cline { 2 - 3 } \cline { 5 - 6 } & verdeling & 5jrs overleving & & verdeling & 5jrs overleving \\
\hline I & $71 \%$ & $90 \%$ & & $29 \%$ & $86 \%$ \\
II & $12 \%$ & $78 \%$ & & $7 \%$ & $70 \%$ \\
III & $14 \%$ & $62 \%$ & & $51 \%$ & $34 \%$ \\
IV & $3 \%$ & $21 \%$ & & $13 \%$ & $19 \%$ \\
\hline
\end{tabular}

Tabel 1. FIGO-verdeling en 5-jaarsoverleving (aangepast uit FIGO Annual Report 2006)

zijn voor uitzaaiingen (metastasen). Dat betekent niet dat ze er niet zijn, want de metastasen kunnen microscopisch klein zijn. Alleen door adequaat te stadiëren en dus bijvoorbeeld lymfklieren tijdens de operatie te verwijderen, kunnen deze microscopische metastasen 
worden herkend. Voor beide ziektebeelden is de kans op het vinden van lymfkliermetastasen bij het klinisch vroege stadium vergelijkbaar. In de literatuur worden percentages genoemd tussen de 5 en $15 \%$ Met andere woorden, bij 5 tot $15 \%$ van de patiënten verandert het klinisch vroege stadium, als gevolg van een adequate stadiëring en het daarbij vinden van lymfkliermetastasen in een gevorderd of FIGO III stadium. En dit heeft, behalve prognostische betekenis, ook vaak therapeutische consequenties. In Nederland doet zich nu de mijns inziens wat merkwaardige situatie voor dat, in tegenstelling tot bij het endometriumcarcinoom en op basis van vergelijkbare criteria, bij het ovariumcarcinoom wel het strikte advies geldt om bij een klinisch vroeg stadium in alle gevallen lymfklieren te verwijderen als onderdeel van de operatie. Bij het ontbreken van metastasen in de verwijderde lymfklieren kan worden afgezien van aanvullende chemotherapie. Criticasters zullen zeggen dat bij het endometriumcarcinoom op zijn minst een groot deel van de patiënten, op basis van andere risicofactoren, al in aanmerking komt voor aanvullende behandeling en het dubieus is of het verwijderen van de lymfklieren uiteindelijk leidt tot een betere prognose. Maar een vergelijkbare argumentatie kan ook worden gevoerd voor het ovariumcarcinoom. Waarom dan deze uiteenlopende adviezen? Wat mij betreft geven opnieuw artspreferenties hierbij de doorslag, in dit geval mogelijk ook gecombineerd met druk vanuit de media. Ik kom daar later nog op terug wanneer ik zal ingaan op de discussie rond centralisatie van zorg en de uitwerking en interpretatie van kwaliteitsindicatoren. Laat duidelijk zijn dat ik mijzelf van dit alles beslist niet vrijpleit en mij realiseer dat bij counseling ook mijn voorkeuren onbewust de patiënt bereiken. Anders kan het toch niet zo zijn dat in het recente verleden nagenoeg iedere patiënt met een endometriumcarcinoom, na mijn uitleg te hebben gehoord, koos voor een lymfadenectomie. Ik heb geprobeerd mijn uitleg aan te passen waarbij ik merkte dat een enkele patiënt er onzeker door werd. Dit nu riep bij mij weer twijfels op of ik er wel goed aan deed de patiënt bij de keuze van het beleid te betrekken. Toch blijf ik die mening toegedaan. Het is een weliswaar moeilijke, maar uiterst belangrijke taak om de patiënt op een adequate manier voor te lichten juist wanneer de beschikbare data complex en soms ook tegenstrijdig zijn. Een belangrijke vraag is hoe dit te bereiken in een voor de patiënt acceptabele en vertrouwd voelende vorm. Dit zal één van de onderwerpen zijn waarop we in Maastricht uitgebreid onderzoek gaan verrichten, een en ander in samenwerking met het team van Hein de Vries, hoogleraar Kankerpreventie, en Ilse Mesters. Sinds jaren 
verrichten zij wetenschappelijk onderzoek naar voorlichtingsmethoden voor kankerpreventie en zijn pioniers in de wereld met betrekking tot het begrip computer-tailoring. Computer-tailoring in de voorlichting kan worden gedefinieerd als het afstemmen van voorlichtingsmateriaal op een specifieke persoon met behulp van een computergestuurd proces. Het verschil met bijvoorbeeld een patiëntvoorlichtingsfolder is dat, afhankelijk van het individu, de voorlichting wordt aangepast waarbij rekening gehouden kan worden met kennisniveau, leeftijd, en eventuele andere factoren. Uiteraard kan computer-tailoring juist ook gebruikt worden om het individu te beïnvloeden en gedragsveranderingen door te voeren, met andere woorden voorkeuren over te brengen. Het voorlichtingsprogramma betreffende therapiekeuzen zal dan ook moeten zijn samengesteld door meerdere personen, liefst met verschillende preferenties. Let wel, en dat wil ik wel benadrukken, het programma maakt slechts onderdeel uit van de arts - patiënt communicatie op basis waarvan uiteindelijk een keuze gemaakt moet worden. De voorlichting mag niet vervallen tot een soort van computerspelletje. Een aantal van u zal ongetwijfeld terecht opmerken dat we er anderzijds voor moeten waken om de beleidsbeslissingen bij de patiënt neer te leggen. Per slot van rekening kunnen patiënten de consequenties onvoldoendeoverzien. Artsen weten dit nueenmaal beteruit ervaring met andere patiënten. Anne Stiggelbout, hoogleraar medisch besliskunde te Leiden, pleit dan ook voor een gedeelde of gezamenlijke besluitvorming. Als we ons als artsen maar realiseren dat onze preferenties vaak niet dezelfde zijn als die van de patiënt.

De besluitvorming rond een individuele patiënt wordt door Stiggelbout als het microniveau omschreven. Besluitvormingen op macroniveau zijn bijvoorbeeld overheidsbeslissingen. Daarbij zijn analyses van kosten versus effectiviteit een belangrijk instrument en is de aandacht minder op het individu gericht. Toch kunnen ook deze beslissingen bij uitstek preferentiegevoelig zijn. Denk bijvoorbeeld aan het recent door minister Ab Klink van de Gezondheidsraad overgenomen advies om de vaccinatie tegen baarmoederhalskanker op te nemen in het Rijksvaccinatieprogramma. Nog altijd is het onderwerp van discussie. De voor- en tegenstanders van dit besluit baseren hun mening op dezelfde bewijslast (de referenties). Zo stellen de voorstanders van vaccinatie dat het de verwachting is dat hierdoor het aantal ziektegevallen, op dit moment ongeveer 600-700 per jaar, en sterftegevallen, ongeveer 200-250 per jaar, gehalveerd zal worden. Daarnaast is het 
de verwachting dat vaccinatie ook het ontstaan van een meervoud aan voorstadia van baarmoederhalskanker tegengaat waarmee behalve medische kosten ook veel patiëntenleed wordt voorkomen. Maar, zeggen de tegenstanders, verwachting staat niet gelijk aan zekerheid. En is deze gezondheidswinst wel omvangrijk genoeg om tot een landelijke vaccinatie over te gaan. Met andere woorden, hoe verhouden zich de kosten tot de effectiviteit. Het vaccin kost per inenting 125 euro en moet drie keer worden toegediend. Op jaarbasis komen ongeveer 100.000 meisjes in aanmerking voor een dergelijke vaccinatie. Al leidt deze mammoetorder ongetwijfeld tot een gereduceerde prijs, dan nog bedragen de kosten enkele tientallen miljoenen euro's per jaar. Dat is een substantieel bedrag, zeker als je daarbij bedenkt dat het lopende bevolkingsonderzoek naar baarmoederhalskanker gehandhaafd moet blijven. Resumerend bevat de bewijslast een aantal onzekerheden waardoor de uiteindelijke meningsvorming in toenemende mate wordt bepaald door eigen expertise en preferenties.

Een ander actueel voorbeeld, waarbij Maastricht dagenlang in het nieuws was, is de pre-implantatie genetische diagnostiek op IVFembryo's naar genetische afwijkingen die kunnen leiden tot een erfelijke vorm van borst- en eierstokkanker. Hierbij zijn vooralsnog de kosten niet de belangrijkste drijfveer om voor of tegen te zijn, maar treden preferentiegevoelige aspecten als ethiek en geloofsovertuiging op de voorgrond.

Naast besluitvorming op micro- en macroniveau benoemt Stiggelbout ook nog het mesoniveau. Het betreft besluitvorming voor een groep van patiënten met dezelfde aandoening. Een voorbeeld hiervan is het maken van regionale of landelijke afspraken en richtlijnen voor medisch handelen die ook kunnen leiden tot een meer uniforme en objectieve informatieverschaffing aan de individuele patiënt. In 2004 zijn, onder voorzitterschap van hoogleraar Gemma Kenter, protocollen voor de diverse gynaecologische maligniteiten uitgewerkt door een multidisciplinaire afvaardiging van belanghebbende specialisten. Deze richtlijnen zijn vervolgens openbaar gemaakt via de website genaamd 'oncoline'. Vooralsnog betreft het hier consensus-based richtlijnen. ledere mening die enig draagvlak heeft, is in de richtlijn opgenomen. Zonder afbreuk te willen doen aan de grote waarde van onze huidige richtlijnen, moet toch gesteld worden dat het structureel inbouwen van wetenschappelijk bewijs een belangrijke toegevoegde waarde zou hebben. Recent heb ik de voorzittershamer mogen overnemen en met 
ondersteuning vanuit de Vereniging van Integrale Kankercentra zal de komende jaren successievelijk iedere richtlijn een meer evidencebased karakter krijgen. We zijn inmiddels begonnen met de richtlijn ovariumcarcinoom. Deze richtlijn zal begin 2009 evidence-based zijn gereviseerd. Bij de inventarisatie en uitwerking van de diverse discussiepunten zijn daarbij overigens niet alleen medische specialisten betrokken, maarookvertegenwoordigersvan paramedischespecialismen, verpleegkundigen en niet in de laatste plaats patiënten. Voor wat betreft de keuze van de uit te werken vragen en knelpunten konden alle leden van de diverse beroeps- en patiëntenverenigingen hun mening laten horen. Opvallend daarbij was dat de top tien van vragen en knelpunten voor nagenoeg alle participerende groeperingen gelijk was. Een tweede opvallende bevinding was dat de wetenschappelijke basis die een antwoord zou moeten geven op vele zo voor de hand liggende vragen nog erg schaars is. De volgende richtlijn die onder handen genomen zal worden is het endometriumcarcinoom. Ik verheug me nu al op de ongetwijfeld pittige discussies die gevoerd gaan worden. Het streven moet zijn dat er een op evidence gebaseerde richtlijn komt waarin ruimte blijft voor eventuele voorkeuren, wensen en verwachtingen van de patiënt zelf, en die anderzijds geen ruimte biedt aan artsen om min of meer vrijblijvend, gerelateerd aan eigen voorkeuren, structureel bepaalde behandelingen wel of niet te adviseren. Dat brengt mij bij een ander onderdeel van de uitwerking van deze richtlijnen, namelijk het opstellen van kwaliteitsindicatoren.

\section{Kwaliteitsindicatoren}

In 1996 is de kwaliteitswet zorginstellingen in werking getreden. Deze wet stelt letterlijk globale kwaliteitseisen en biedt zo instellingen de ruimte haar eigen kwaliteitsbeleid verder te ontwikkelen. Echter, een en ander heeft tot op dit moment geleid tot de ontwikkeling van diverse algemene en via internet beschikbare kwaliteitsindicatoren die inzicht zouden moeten geven in de kwaliteit van zorg in de desbetreffende instellingen. Bekende indicatoren zijn bijvoorbeeld wachttijden, incidentie van doorligplekken, overlijden na beroerte, percentage heroperaties aan dikke darm et cetera. Deze indicatoren worden inmiddels, al dan niet gecombineerd met diverse andere per enquête verkregen ziekenhuisgegevens, in de media populair vertaald in ranglijsten.

Laat ik voorop stellen dat deze ontwikkeling een belangrijke bijdrage kan leveren aan de verbetering van de zorg. Het openbaar maken van 
kwaliteitsindicatoren is met de huidige marktwerking niet alleen niet tegen te houden, de patiënt heeft ook het recht op inzage in dergelijke gegevens. Het is dan echter wel belangrijk dat er indicatoren gebruikt worden die in overeenstemming zijn met de doelen die ermee bereikt moeten worden. Daarmee kan de analyse van kwaliteitsindicatoren behoorlijk ingewikkeld worden. Een simpel voorbeeld zijn de wachttijden: waar voor de ene patiënt met een betrekkelijk eenvoudig medisch probleem de wachttijd van groot belang is, zou voor een andere patiënt een adequate en kwalitatief hoogstaande multidisciplinaire benadering moeten prevaleren boven een wat kortere wachttijd. Dus door alleen te kijken naar wachttijden loopt de patiënt het risico in een ziekenhuis behandeld te worden waar nu juist de kwaliteit van zorg op dat onderdeel twijfelachtig zou kunnen zijn. Neem een ander concreet voorbeeld binnen de gynaecologische oncologie. Bij een gevorderd stadium ovariumcarcinoom kan het percentage patiënten waarbij een complete debulking wordt bereikt als kwaliteitsindicator gelden. Van een complete debulking wordt gesproken wanneer tijdens de operatie al het zichtbare kwaadaardige weefsel is verwijderd. Dit is uiteraard afhankelijk van de kunde van de operateur(s). Maar wat bijvoorbeeld te denken van een binnen de regio gemaakte afspraak, dat patiënten met een evident gevorderd stadium ovariumcarcinoom worden verwezen naar het centrum. Dit zou kunnen leiden tot de toch merkwaardige situatie dat het centrumziekenhuis binnen deze regio uiteindelijk de slechtste score behaalt. Binnen de obstetrie wordt al ingespeeld op variabelen die van invloed kunnen zijn op kwaliteitsindicatoren door het gebruik van zogenaamde VOKS-percentielen. VOKS staat voor Verloskundige Onderlinge Kwaliteits Spiegeling. Neem als voorbeeld het percentage keizersneden in een praktijk. Het zal duidelijk zijn dat in een ziekenhuis dat fungeert als centrum voor gecompliceerde zwangerschappen dit percentage hoger ligt dan in een niet-centrum ziekenhuis. In de VOKS wordt het percentage keizersneden van een praktijk gecorrigeerd voor 15 factoren waardoor een betere onderlinge vergelijking mogelijk wordt. Concluderend is het uitwerken van een goede kwaliteitsindicator een uiterst ingewikkelde aangelegenheid. Dit laat onverlet dat kwaliteitsindicatoren ook binnen de gynaecologische oncologie van groot belang zijn. Een belangrijke vereiste om deze indicatoren op een nette en betrouwbare manier uit te werken, is een op zijn minst regionale maar liefst landelijke dataregistratie. 


\section{Centralisatie van zorg}

Alvorens wat uitgebreider in te gaan op het onderwerp dataregistratie, wil ik eerst ingaan op de infrastructuur van de gynaecologisch oncologische zorg in Nederland. In het verleden zijn daarover binnen de Nederlandse Vereniging voor Obstetrie en Gynaecologie, vaak op instigatie van de Werkgroep Oncologische Gynaecologie, diverse nota's en rapporten opgesteld. Daarbij werd onder andere een taakverdeling tussen ziekenhuizen nagestreefd: spreiding waar mogelijk, concentratie waar nodig. Met vele van de voorwaarden en eisen kon ik instemmen. Maar ik heb me ook regelmatig afgezet tegen de noodzaak tot centralisatie gebaseerd op authority-based meningen dat de centra nu eenmaal beter presteerden, zonder enige onderbouwing met adequaat uitgewerkte kwaliteitsindicatoren. Recent zijn op initiatief van emeritus hoogleraar Peter Heintz landelijke data beschikbaar gekomen over de behandeling van het ovariumcarcinoom. De conclusies van dit onderzoek, waarop Floor Vernooij is gepromoveerd, hebben het afgelopen jaar veel aandacht gekregen in de media. Kleinere ziekenhuizen scoren significant slechter waar het de overleving betreft zonder dat daarbij overigens een uitspraak gedaan kan worden over ieder individueel ziekenhuis. Echter de resultaten van de grotere niet-centrum ziekenhuizen (het woordje 'perifeer' spreekt mij minder aan) zijn vergelijkbaar met de centrum ziekenhuizen. Daarnaast blijkt dat de resultaten minder goed zijn dan die van diverse buitenlandse centra. Met andere woorden, de conclusie is niet alleen dat er verschillen zijn tussen de diverse ziekenhuizen, maar ook dat de centra zelf beter moeten gaan presteren.

$\mathrm{Nu}$ moet het vergelijken van data met andere landen wel kritisch beoordeeld worden. Laten we als voorbeeld nemen het gevorderd FIGO III stadium ovariumcarcinoom. In de studie van Vernooij wordt voor de periode 1996 tot en met 2003 en van toepassing op de gehele Nederlandse populatie, een relatieve vijfjaarsoverleving opgegeven van $25 \%$. Met andere woorden na vijf jaar is $75 \%$ van deze patiëntengroep overleden waarbij de doodsoorzaak direct gerelateerd is aan het ovariumcarcinoom. Wanneer we dit percentage vergelijken met de data die we kunnen afleiden uit een recente studie van de Amerikaanse Gynecologic Oncology Group (GOG) met als inclusieperiode 1998 tot en met 2001, dan wordt voor dezelfde patiëntengroep en behandeld op een vergelijkbare manier, een vijfjaarsoverleving gevonden van $40 \%$. Deze studie was opgezet om de waarde van een opnieuw geïntroduceerde behandelingstechniek, namelijk intraperitoneale chemotherapie, te beoordelen. Wanneer behandeld met deze nieuwe techniek bedroeg 
de vijfjaarsoverleving zelfs $49 \%$. Voor de kenners onder ons: daarbij ga ik er gemakshalve maar even van uit dat in deze concrete situatie de absolute en relatieve vijfjaarsoverleving vergelijkbaar zijn. Dit lijken op het eerste oog toch wel forse verschillen. Maar bedenk dan dat de patiëntengroep binnen de GOG-studie een sterk geselecteerde populatie betrof. De geïncludeerde patiënten hadden allen een goede lichamelijke gezondheid, en bij allen diende een optimale debulkingoperatie te zijn verricht, anders werden ze niet in de studie opgenomen. Dus is deze vergelijking niet gerechtvaardigd. Via de database van het National Cancer Institute hebben we ook meer algemene Amerikaanse cijfers. Voor de jaren 1996 tot en met 2004 wordt een vijfjaarsoverleving opgegeven van $31 \%$. Dus ook nog altijd beduidend beter dan die voor de Nederlandse populatie. Maar deze Amerikaanse cijfers zijn gebaseerd op slechts $26 \%$ van de gehele Amerikaanse populatie. Mogelijk dat het percentage voor de gehele populatie hoger of lager ligt. Dit alles neemt niet weg dat we in Nederland beter kunnen en ook moeten presteren. Hoe kunnen we dit realiseren. Centrum en grotere niet-centrum ziekenhuizen hebben vergelijkbare resultaten. Dit zou uitgelegd kunnen worden als dat, zo lang de centra niet beter presteren, centralisatie van bepaalde categorieën van patiënten met een ovariumcarcinoom niet noodzakelijk is. Maar dan sluit ik mij aan bij een uitspraak van emeritus hoogleraar gynaecologische oncologie Henk Boonstra, begin dit jaar onverwachts en te vroeg overleden, met wie ik ook menig keer over dit onderwerp gediscussieerd heb. Hij stelde tijdens zijn oratie in 1998 dat "het verwijzen naar centra ook moet worden gezien als een mogelijkheid voor deze centra om zich verder te kunnen ontplooien, de benodigde ervaring op te doen en uiteindelijk in stand te houden." Met andere woorden, om beter te worden heb je grote patiëntenaantallen nodig. Ook dat blijkt uit de data-analyse van Vernooij: de ziekenhuizen met de grotere aantallen hebben de beste resultaten. Om dit te bereiken is samenwerking een eerste vereiste. Op dit moment ben ik nog altijd van mening dat de in Nederland inmiddels gangbare consulentfunctie voor gynaecologisch oncologen voor diverse patiëntcategorieën een goede structuur is en kan leiden tot een optimale kwaliteit van zorg. Deze consulentfunctie houdt in dat de gynaecologisch oncoloog op locatie, dus in de niet-centrum ziekenhuizen, deelneemt aan oncologische operaties. Hierbij valt bijvoorbeeld te denken aan patiënten met de verdenking op een vroeg-stadium ovariumcarcinoom. Bij bevestiging van de diagnose tijdens de operatie door middel van een zogenaamd vriescoupe-onderzoek, kan direct een adequate stadiëring (met 
lymfklieren) uitgevoerd worden. Met gebruikmaking van prognostische modellen kan het aantal keren dat de gynaecologisch oncoloog voor niets afreist worden teruggebracht tot acceptabele aantallen. Natuurlijk zijn aan een dergelijke samenwerkingsstructuur extra kosten verbonden. Deze staan op gespannen voet met de huidige ontwikkelingen waarbij het voor zorgverzekeraars zeer verleidelijk is de marktwerking ook in dit segment van de zorg te introduceren. Ik heb niets tegen kosten versus baten analyses, als daarbij het uiteindelijke resultaat van deze zorg (de baten) maar blijft prevaleren. Anderzijds, en dan kom ik terug op de centralisatie van zorg, acht ik het noodzakelijk dat andere patiëntcategorieën, namelijk die waarbij de kans op zeer uitgebreide chirurgie groot is, wel degelijk naar het centrum worden verwezen om zo de centra de mogelijkheid te geven zich verder te ontplooien in deze vorm van behandeling. Dit alles uiteraard met inachtneming van de voorkeuren en verwachtingen van de patiënt en met een adequate dataregistratie ter bewaking van de kwaliteit van zorg.

\section{Dataregistratie}

Al enkele malen heb ik registratie genoemd. Het is mij dan ook een doorn in het oog dat gynaecologisch oncologisch Nederland geen solide landelijke registratie heeft. Daarom hebben we geen mogelijkheden om betrouwbare kwaliteitsindicatoren uit te werken. Binnen de IKZ-regio hebben we de afgelopen jaren veel tijd en energie geïnvesteerd in een web-based registratieprogramma. Dit programma, ROGY genaamd, is in 2006 operationeel geworden in deze regio. Het biedt vele mogelijkheden ter bewaking van de kwaliteit van zorg. Zo worden de data gebruikt voor de regionale patiëntbesprekingen en een regionaal jaarverslag. En uiteraard vormt het een uitstekende basis voor wetenschappelijk onderzoek. Binnen de IKL-regio hopen we begin 2009 eenzelfde registratie te starten. Als het aan mij ligt hebben we binnen vijf jaar in Nederland een Landelijke Oncologische Registratie of LOR, in analogie aan de Landelijke Verloskundige Registratie of LVR. In de verloskunde hebben we allemaal wel eens kritiek op de uitvoerige lijst die moet worden ingevuld na iedere bevalling, maar desondanks doen we er allemaal aan mee. Als beloning krijgen we ieder jaar een fraai overzicht van onze resultaten aangevuld met de VOKS-statistieken. Kijk naar de consequenties, iedere kliniek probeert zijn cijfers te verbeteren daar waar deze in vergelijking met het gemiddelde slechter scoren. De afgelopen jaren hebben zich ook de IVF-centra gemanifesteerd met de Landelijke Infertiliteit Registratie, de LIR. Wat let ons om ook de 
gynaecologische oncologie op deze manier op de kaart te zetten. Ik ben bereid hierin de nodige tijd te investeren.

\section{Wetenschappelijk onderzoek}

Op het terrein van onderzoek noemde ik u al de ideeën rondom computertailoring en het gebruik hiervan bij de counseling van patiënten voor wat betreft de therapiekeuze. Maar deze techniek kan ook uitstekend van pas komen bij de follow-up. In Amerika is voor patiënten bij wie de primaire behandeling is afgerond, het zogenaamde survivorship care plan sterk in ontwikkeling. Het betreft een specifiek voor de patiënt opgesteld document met gedetailleerde informatie rondom haar ziekte, de uitgevoerde behandeling, potentiële vroege en late bijwerkingen, recidiefkans en klachten die daarop kunnen duiden en het voorgestelde follow-up schema. Mogelijk dat het principe van computer-tailoring nog een extra dimensie kan toevoegen. Of een dergelijk begeleidingstraject voor de patiënt een evidente meerwaarde heeft zal moeten worden onderzocht, het liefst in de vorm van een gerandomiseerd onderzoek. Op dit moment wordt, mede op initiatief van Lonneke van de Poll, als epidemioloog werkzaam bij het IKZ en de Universiteit van Tilburg, een onderzoeksprotocol dienaangaande uitgewerkt. Daarbij zal door de participerende ziekenhuizen binnen de IKL en IKZ-regio, ik benadruk het nog maar een keer, dankbaar gebruik worden gemaakt van de regionale dataregistratie.

Een ander onderzoeksterrein dat mijn speciale interesse heeft, is de lymfklierstatus bij gynaecologische maligniteiten en meer in het bijzonder het endometriumcarcinoom. Uit mijn betoog is duidelijk geworden dat we tot op dit moment nog onvoldoende accurate preoperatieve technieken hebben om de patiënten met een verhoogd risico op lymfkliermetastasen te herkennen. Recent zijn we in Maastricht, in samenwerking met Regina Beets-Tan, hoogleraar radiologie, gestart met een veelbelovende nieuwe radiologische techniek om zeer kleine lymfkliermetastasen op te sporen. Daarnaast gaan we participeren in het onderzoeksproject van hoogleraar Rene Verheijen van het Universitair Medisch Centrum Utrecht, gericht op de schildwachtersklierprocedure bij baarmoederhalskanker. Voor wat betreft de gynaecologische maligniteiten heeft deze techniek zich al bewezen bij schaamlipkanker. Hierdoor kan het aantal te verwijderen lymfklieren vaak beperkt blijven, met een duidelijk gunstig effect op de kwaliteit van leven na de behandeling. Bij andere gynaecologische maligniteiten is het echter nog de vraag of de schildwachtersklierprocedure toekomst heeft. 
Maar de uiteindelijke toekomst ligt met zekerheid in de moleculaire oncologie. De afgelopen maanden hebben we in Maastricht enkele brainstormsessies gehad met diverse afdelingen en disciplines binnen de universiteit. Ik verwacht dat we in de komende jaren ook meer basaal wetenschappelijk onderzoek zullen initiëren.

\section{Onderwijs}

Tot slot wil ik stilstaan bij het onderwijs hier in Maastricht en dat wil ik doen door weer terug te gaan naar mijn eerste onderwerp, evidencebased medicine (EBM). Zoals gezegd, werd het EBM-denken in de jaren tachtig van de vorige eeuw ontwikkeld en heeft het zich in de huidige tijd, samen met de aandacht voor de individuele patiënt, o.a. vertaald in het begrip 'PICO'. Hierbij staat de P voor Patient of Problem, I voor Intervention, $\mathrm{C}$ voor Comparison, en O voor Outcome. Kortom, de patiënt met haar probleem staat centraal, en voor deze patiënt wordt gezocht naar bewijsmateriaal voor de beste therapie. De faculteit Geneeskunde in Maastricht is in 1974 van start gegaan en heeft toen een nieuwe onderwijsvorm geïntroduceerd, namelijk het probleemgestuurde onderwijs als tegenhanger van het traditionele frontale onderwijs. Begrippen als zelfwerkzaamheid, samenwerken, en praktijkgericht studeren staan daarbij centraal. Maastricht werd door de andere medische faculteiten in eerste instantie met argwaan gevolgd. Nu blijkt dat Maastricht zijn tijd ver vooruit was, ja eigenlijk mede grondlegger was van de 'PICO'. Door studenten wordt dit onderwijs nog altijd zeer gewaardeerd. Dit valt af te leiden uit de ook binnen het onderwijs inmiddels populaire ranglijsten (figuur 3). Eerder heb ik al aangegeven dat de waarde van dergelijke ranglijsten, in dit geval gebaseerd op enquêtes onder studenten en hoogleraren, niet moet worden overschat. Maar het kan natuurlijk geen kwaad wanneer je over langere tijd de lijst aanvoert, waarbij overigens de verschillen in eindscore tussen de diverse medische faculteiten de laatste jaren marginaal zijn geworden. Mogelijk wordt dit verklaard door het feit dat ook het onderwijs tegenwoordig wetenschappelijk wordt beoordeeld en dus preferenties minder op de voorgrond treden. Parallel met de term 'evidence-based medicine' binnen de geneeskunde is in het medische onderwijs de term 'best evidence-based medical education' geïntroduceerd. Nederland, en meer in het bijzonder Maastricht, heeft hierin een uiterst actieve rol. Recent heb ik met goed gevolg deelgenomen aan de basiscursus 'probleem gestuurd onderwijs'. De komende jaren wil ik met plezier een bijdrage leveren aan het specifieke Maastrichtse medische onderwijs. 
Dames en heren, ik ben aan het einde gekomen van mijn betoog. Ik heb $u$ laten zien dat, hoezeer we ook ons best doen om evidence-based beslissingen te nemen op zowel micro-, meso-, en macroniveau, deze nagenoeg altijd nog gekleurd worden door preferenties. Dit is niet erg, als we als professionals maar bereid zijn dit als zodanig te herkennen en erkennen. Dit zal leiden tot meer begrip voor zowel de preferenties van de patiënt als voor elkaars standpunten. Ik heb $u$ laten zien dat het uitwerken van betrouwbare kwaliteitsindicatoren een ingewikkelde aangelegenheid is, maar noodzakelijk om inzicht te krijgen in de kwaliteit van zorg en een stimulans om daar waar nodig verbeteringen aan te brengen. Ik hoop $\mathrm{u}$ te hebben overtuigd, dat voor het verkrijgen van betrouwbare kwaliteitsindicatoren het hebben van een landelijke databank een eerste vereiste is.

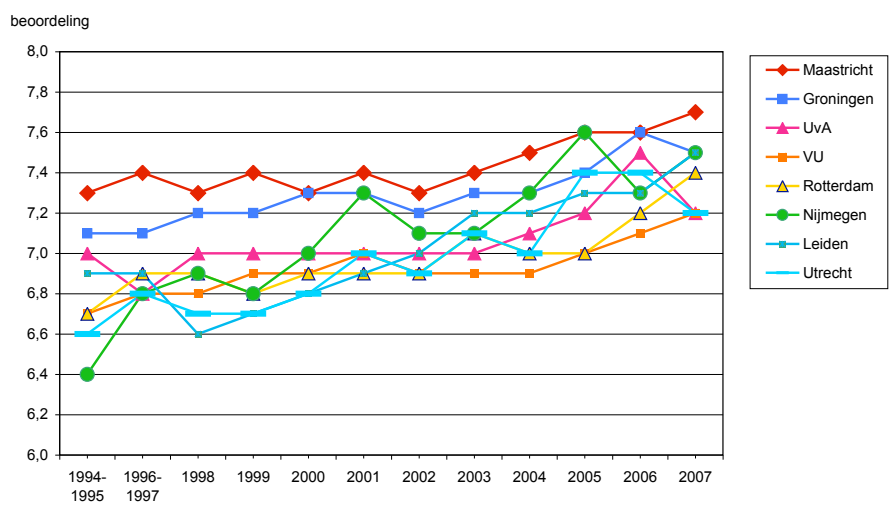

Figuur 3. Elsevier/NIPO-enquête 1994-2007: waardering per medische faculteit

Ik wil $\mathrm{u}$ allen danken voor uw belangstelling en aanwezigheid. Tot slot, hoogleraar worden doe je niet in je eentje. De lijst van personen die ik eigenlijk zou willen bedanken is veel te lang om hier uit te spreken. Daarom zal ik dan ook vaker groepen van personen noemen dan afzonderlijke namen. 


\section{Dankwoord}

Leden van de Raad van Bestuur van het Maastricht Universitair Medisch Centrum en in het bijzonder Guy Peters. Leden van het College van Bestuur van de Universiteit van Maastricht, de Decaan van de Faculteit of Health, Medicine and Life Sciences alsmede de voormalig Decaan de hooggeleerde Harry Hillen. $U$ allen dank ik voor het in mij gestelde vertrouwen op basis waarvan $u$ mij hebt benoemd tot profileringhoogleraar Gynaecologische Oncologie. Ik ga mijn uiterste best doen om aan uw verwachtingen, ook waar het de wetenschap betreft, te voldoen.

Een aantal personen hebben veel voor mij betekend tijdens mijn opleiding tot gynaecoloog. In het bijzonder wil ik hier noemen de hooggeleerde Tom Eskes, Peter Kenemans, en Rune Rolland. Maar ook moeten genoemd worden Rinze de Boer, Bert Broeders, Julien Dony, en Charles Schijf. Zij hebben mij mede gevormd tot de gynaecoloog die ik nu ben, waarvoor dank. Daarnaast werd mij de mogelijkheid geboden om, parallel met mijn opleiding, een promotietraject te doorlopen. Daarbij werd ik gesteund door velen en in het bijzonder wil ik hier noemen Wim Willemsen, Lambert Poels, en Paul Jap.

De afgelopen 17 jaar was ik werkzaam in Brabant. De eerste 9 jaar in Den Bosch. Mijn toenmalige maatschapsleden dank ik voor de mogelijkheden die zij mij hebben geboden om mij verder te specialiseren in de gynaecologische oncologie. Mede daardoor maakte ik in 2000 de overstap naar Tilburg waar ik terecht kwam in, en dat durf ik te zeggen zonder te blozen, de beste (niet-academische) vakgroep van Nederland, namelijk de vakgroep Gynaecologie / Obstetrie van het TweeSteden ziekenhuis. Zij vormden dan ook de reden dat ik lang getwijfeld heb of ik wel moest ingaan op het aanbod uit Maastricht. Ik wil mijn voorganger in Tilburg, Hans Kock, toch even apart memoreren. Hans is helaas niet meer in staat bij deze gelegenheid aanwezig te zijn. Toch wil ik gezegd hebben dat ik de van hem geleerde "pluktechniek" nog altijd toepas, en regelmatig bij het onderwijzen van deze techniek aan anderen zeer enthousiaste reacties krijg. Ik heb een fantastische tijd gehad in Tilburg. En met het noemen van de vakgroep moet ik ook alle medewerkers van de afdeling Gynaecologie en Obstetrie noemen.

In mijn Brabantse tijd heb ik intensief met het IKZ van doen gehad. Met het IKZ moet ik natuurlijk ook het OOG-IKZ noemen. Het OOG-IKZ is een voorbeeld voor Nederland waar het de gynaecologisch-oncologische 
samenwerking betreft. Ik wil dan ook zonder uitzondering alle collegae binnen het OOG-IKZ en personeelsleden van het IKZ danken voor de samenwerking. In het bijzonder wil ik noemen Janny van den Eijnde en Hans van der Putten.

Kort voor mijn komst naar Maastricht was ik ook nog kortdurend werkzaam in Nijmegen. Het gynaecologisch oncologisch team aldaar, onder leiding van Leon Massuger, vormt een hechte groep met ieder een eigen inbreng daarin. Ondanks de korte periode dat ik met jullie heb gewerkt, heb ik erg veel geleerd. Ik hoop van harte dat we op enigerlei wijze kunnen blijven samenwerken.

En dan natuurlijk de medewerkers en collegae van de vakgroep Gynaecologie en Obstetrie te Maastricht. Al tijdens het allereerste gesprek werden mijn initiële twijfels weggenomen hetgeen het uiteindelijke besluit om afscheid te nemen van mijn maten in Tilburg vergemakkelijkte. Ik voelde mij direct thuis in Maastricht. De hooggeleerde Nijhuis wil ik hierbij apart noemen. Jan en ik hadden al eens academisch met elkaar samengewerkt in Nijmegen. Hij als jonge specialist, ik als AIO. We konden het toen al goed met elkaar vinden, en dat is wat mij betreft niet veranderd. Natuurlijk moet ik hier ook de leden van de gynaecologisch-oncologische pijler vermelden. Op de allereerste plaats Brigitte Slangen, aan wie Maastricht te danken heeft dat de gynaecologisch-oncologische pijler überhaupt nog bestaat. Hans Trum wiens enthousiasme om nu nog aan een fellowship te beginnen aangeeft hoeveel energie hij in zich heeft. En die komt de komende jaren goed van pas. Jan Stoot, die gelukkig bereid was (met instemming van zijn vroegere maten te Heerlen) om Brigitte de helpende hand te bieden in de fase die nu achter ons ligt. Zijn kennis en kunde, gebaseerd op een enorme ervaring, waren en zijn van onschatbare waarde. En Petra op den Oordt. Al in de fase dat mijn benoeming in Maastricht nog niet definitief was, werd mij duidelijk dat ook zij een uiterst belangrijke rol vervulde binnen het gynaecologisch oncologische team. Petra is een duizendpoot en behoudt onder alle omstandigheden een opgewekte stemming wat weer een stimulerend effect heeft op ons allemaal.

En dan nog enkele personen met wie ik geen 'medische' relatie heb. Mijn ouders, beiden hier nog aanwezig, maar zeker ook mijn schoonouders. Zij hebben mij op vele manieren bijgestaan en gestimuleerd. 
En tot slot mijn gezin. Sander, Elmar, Marloes. Jullie allen staan inmiddels op eigen benen maar vormden eerder met Marian een super thuisfront. Om uiteenlopende redenen ben ik trots op jullie allemaal. En Marian. Zonder jou zou ik hier nu niet staan, laat dat voor iedereen duidelijk zijn. We hebben al een groot aantal verhuizingen achter de rug en met zekerheid ligt er in ieder geval nog één in het verschiet. Steeds stem jij in met een nieuwe fase in mijn carrière. Dank voor alle steun.

Ik heb gezegd. 


\section{Referenties}

- Amant F, Moerman P, Neven P, Timmerman D, Limbergen E van, Vergote I: Endometrial cancer. Lancet 366:491-505, 2005.

- Angioli R, Plotti F, Palaia I, Calcagno M, Montera R, Cafa EV, Sereni MI, Panici PB: Update on lymphadenectomy in early and advanced ovarian cancer. Cur Opin Obstet Gynecol 20:34-39, 2008

- Armstrong DK, Bundy B, Wenzel L, Huang HQ, Baergen R, Lele S, Copeland LJ, Walker JL, Burger RA: Intraperitoneal Cisplatin and Paclitaxel in Ovarian Cancer (GOG-172). N Engl J Med 354:34-43, 2006.

- Bensing J: Bridging the gap. The separate worlds of evidence-based medicine and patient-centered medicine. Patient Educ Couns 39:17-25, 2000.

- Berman ML: Adjuvant radiotherapy following properly staged endometrial cancer: what role? Gynecol Oncol 92:737-739, 2004.

- Boonstra H: De zorg centraal en het centrale in de zorg. Oratie, Katholieke Universiteit Nijmegen, 1998.

- Creutzberg CL: GOG-99: ending the controversy regarding pelvic radiotherapy for endometrial carcinoma? Gynecol Oncol 92:740-743, 2004.

- FIGO annual report 2006.

- Heintz P, Vernooij F, Witteveen E, Graaf Y vd: Concentratie loont. Behandeling ovariumcarcinoom in Nederland onder de maat. Medisch Contact 63:800-804, 2008.

- Herzog TJ: Assessing the adequacy of surgical staging for ovarian cancer. Gynecol Oncol 103:781-782, 2006.

- Hope T: Evidence-based patient choice and psychiatry. Evid Based Ment Health 5:100-101, 2002.

- Kerkhof M: Let op de bel s.v.p. NRC Handelsblad, 2008.

- Keys HM, Roberts JA, Brunetto VL, Zaino RJ, Spirtos NM, Bloss JD, Pearlman A, Maiman MA, Bell JG: A phase III trial of surgery with or without adjunctive external pelvic radiation therapy in intermediate risk endometrial adenocarcinoma: a Gynecologic Oncology Group study Gynecol Oncol 92:744-751, 2004.

- Kremer JAM: Patient-power in vruchtbare netwerken. Oratie, Radboud Universiteit Nijmegen, 2007.

- NVOG Notitie WAGON.

- NVOG Notitie KLINKER, 1996.

- NVOG Nota Oncologie 2000.

- Nooijer J de, Lechner L, Vries H de: Tailored versus general information on early detection of cancer: a comparison of the reactions of Dutch 
adults and the impact on attitudes and behaviors. Health Educ Res 17:239-252, 2002.

- NOW Spinoza-premies 2006.

- Offringa M, Assendelft WJJ, Scholten RJPM: Inleiding in evidencebased medicine. Bohn Stafleu van Loghum. Tweede, herziene druk, vierde oplage, 2007.

- Oncoline. www.oncoline.nl.

- Paulides JJ, Lennards CALM, Jongejan B: Cultuuromslag in de oncologie. Medisch Contact 60:348-350, 2005.

- Sackett DL, Rosenberg WMC, Gray JAM, Haynes RB, Richardson WS: Evidence based medicine: what it is and what it isn't. BMJ 312:71-72, 1996.

- Scherpbier A: De Maastrichtse onderwijsbenadering. Oratie Universiteit Maastricht, 2000.

- Surveillance Epidemiology and End Results (SEER). National Cancer Institute. www.cancer.gov/statistiscs/ .

- Stiggelbout A: Kiezen of delen? De rol van patientpreferenties in de besluitvorming. Oratie Universiteit Leiden, 2008.

- Trimbos JB, Vergote I, Bolis G, Vermorken JB, Mangioni C, Madronal C, Franchi M, Tateo S, Zanetta G, Scarfone G, Giurgea L, Timmers P, Coens C, Pecorelli S: Impact of Adjuvant Chemotherapy and Surgical Staging in Early-Stage Ovarian Carcinoma: European Organisation for Research and Treatment of Cancer-Adjuvant ChemoTherapy in Ovarian Neoplasm Trial. J Nat Cancer Inst 95: 113-125, 2003.

- Vernooij F: Ovarian cancer treatment in The Netherlands. Thesis, 2008. 
